\title{
Blue-stain Fungi Associated with Roots of Southern Pine Trees Attacked by the Southern Pine Beetle, Dendroctonus frontalis
}

William J. Otrosina, Supervisory Research Plant Pathologist, USDA Forest Service, Southern Research Station, Athens, GA, 30602; Nolan J. Hess, Plant Pathologist, USDA Forest Service, Forest Health Staff, Alexandria Field Office, Pineville, LA, 71360; Stanley J. Zarnoch, USDA Forest Service, Southern Research Station, Asheville, NC 28802; Thelma J. Perry, USDA Forest Service, Southern Research Station, 2500 Shreveport Highway, Pineville, LA, 71360; and John P. Jones, Professor, Department of Plant Pathology, Louisiana State University, Baton Rouge 70893

\begin{abstract}
Otrosina, W. J., Hess, N. J., Zarnoch, S. J., Perry, T. J., and Jones, J. P. 1997. Blue-stain fungi associated with roots of southern pine trees attacked by the southern pine beetle, Dendroctonus frontalis. Plant Dis. 81:942-945.

Forty paired plots were established from eastern Texas to Alabama to study root-infecting, bluestain fungi in southern pine stands undergoing southern pine beetle (SPB) attack. Woody roots were sampled in plots undergoing recent or current attack by the SPB. Comparisons were made between occurrence of Leptographium spp. and related fungi and data on various characteristics of natural stands and plantations studied. Three fungal species, L. terebrantis, L. procerum, and Ophiostoma ips, along with unidentified Leptographium and Graphium species, were isolated from sampled roots. L. terebrantis was isolated more frequently from SPB-attacked plots $(P<$ 0.001 ) than was either $L$. procerum or $O$. ips. More blue-stain fungal species and related genera were isolated from SPB-attacked plots than from control plots $(P<0.001)$. This also was true for combined isolation percentages of $L$. terebrantis, $L$. procerum, and $O$. ips $(P=0.03)$. Presence of blue-stain fungi also was associated with higher stand basal area in the control plots $(P$ $=0.045$ ). Isolation frequencies of $O$. ips and $L$. procerum, along with the combination of these fungal species with $L$. terebrantis, were logistically related to increasing stand basal area in the control plots $(P=0.02,0.02$, and 0.01 , respectively). No logistic relationship was found for frequency of any of the three blue-stain species with respect to basal area in SPB-attacked plots. These results suggest blue stain fungi are important in the dynamics of susceptibility of southern pines to SPB attack.
\end{abstract}

There is considerable evidence linking the presence of root diseases and treekilling bark beetle attacks in conifers in the western United States $(6,7,13,18)$. In the southeastern United States, the root-disease causing fungus, Heterobasidion annosum Fr. (Bref.), has been associated with susceptibility of loblolly pine (Pinus taeda L.) to attack by the southern pine beetle, Dendroctonus frontalis Zimm. (Coleoptera: Scolytidae) (1). Recent studies have revealed other root pathogens that are associated with trees exhibiting decline symptoms in plantations and natural stands $(3,4,18)$.

Root infecting fungi belonging to the genera Leptographium Lagerb. \& Melin and Ophiostoma H.\& P. Sydow have been studied largely with respect to their rela-

Corresponding author: W. J. Otrosina

E-mail: otrosina@negia.net

Accepted for publication 9 May 1997

Publication no. D-1997-0602-01R

This article is in the public domain and not copyrightable. It may be freely reprinted with customary crediting of the source. The American Phytopathological Society, 1997. tionships with bark beetles (11). These fungi are commonly associated with bark beetles either as pathogens or as casual associates found in beetle galleries (9). Pathological relationships relative to their presence in roots and their role in predisposition of conifers to stem-attacking bark beetles have not been established for many of these fungi. This is especially true regarding the association of these fungi with pine roots and their possible role in processes involved in southern pine beetle (SPB) attack. Also, little is known of the distribution of Leptographium species in pine roots and their relationships to this economically and ecologically important bark beetle. The objectives of this study were to 1) determine the distribution and frequency of Leptographium species and related fungi in southern pine stands under SPB attack and 2) determine stand characteristics associated with occurrence of these root disease fungi.

\section{MATERIALS AND METHODS}

Forty paired, variable-radius plots were established in southern pine stands over a broad geographic area. Thirty-one of the 40 paired plots were located in loblolly pine stands, four were in slash pine (Pinus elliottii Engelm.) stands, four in mixed loblolly and slash pine stands, and one in a longleaf pine (Pinus palustris Mill.) stand. The plot locations ranged from Alabama to Texas and represent a wide variety of southern pine sites. (Exact details of plot locations are available from the senior author.) Plot establishment was determined by locating SPB-attacked pine trees using the Southern Pine Beetle Information System (SPBIS), a computerized tracking system designed to identify and locate active beetle attack spots (12). The majority of these active SPB attack spots were located within 1 month of attack initiation. For each SPB plot, a control plot was established by traversing a line in a cardinal direction a distance of $80.5 \mathrm{~m}$ from the due north edge of the SPB plot. The control plots are presumed to represent stand and site conditions present in the SPB-attacked plots.

In each of the control and SPB plots, data on tree species, diameter at breast height $(\mathrm{DBH})$, pine basal area, tree height, radial growth increment, soil texture, aspect, stand basal area, and evidence of previous site disturbance were recorded. Trees used for determining DBH and radial growth measurements were obtained by selecting three dominant or codominant trees nearest the plot center. The height measurement used to obtain site index values for each SPB and control plot was measured by randomly selecting one of the three trees closest to the plot center.

Roots from the three trees in each plot were sampled using a modified two-root excavation method (2). All root samples were taken within 30-40 days of initial attack dates recorded on SPBIS records. Two primary lateral root segments greater than $3 \mathrm{~cm}$ in diameter from each of the three plot trees were excavated with hand tools to a distance of approximately $1 \mathrm{~m}$ from the root collar. Twenty-centimeterlong sections of root were cut beginning at 16 and $50 \mathrm{~cm}$ from the root collar from each root. The samples from each tree were placed in a plastic bag and kept chilled in ice chests no longer than $48 \mathrm{~h}$ before transportation to the laboratory. Two hundred and forty trees were sampled on the 80 plots in this study. 
Root samples were washed under running tap water, air dried, and cut into $1 \mathrm{~cm}$ $\times 0.5 \mathrm{~cm}$ sections. The wood sections were surface disinfected by immersing in $95 \%$ ethyl alcohol and flaming briefly. Three sections from the $16-$ and $50-\mathrm{cm}$ portions of each root segment from each tree were placed on each of three plates of malt extract agar (MEA), ortho-phenyl phenol medium (2), and cycloheximide amended malt extract medium (14). When staining or resinosis was observed on root samples, isolations were made at the margins of such features. Otherwise, isolations were made from several points along the root sample. Subcultures were made from plates exhibiting fungal growth for identification and further study.

The study design was a randomized block design in which each block consisted of a SPB-attacked plot and a non-attacked control plot. Thus, the overall study had 40 blocks. Test of differences in stand characteristics between SPB and control plots used a standard randomized block analysis. Because there were only two treatments, the analysis was equivalent to a paired $t$ test. Analysis of presence or absence of blue-stain fungi was on a plot basis, where one confirmed fungal isolate from one tree in a plot was sufficient to score that plot positive. Differences in proportion of SPB and control plots with blue-stain fungi utilized the McNemar test (5), taking into account the blocking structure of the study. Logistic regression methods using PROC LOGIST (SAS Institute Inc., Cary, NC) were used to model the association between blue-stain fungi and stand conditions.

\section{RESULTS}

Cycloheximide-amended and unamended MEA were equally effective in isolating blue-stain fungi. The fungal species isolated from the root samples were $O$. ips (Rumb.) C. Moreau, L. terebrantis Barras $\&$ Perry, and L. procerum (Kendr.) Wingfield. $H$. annosum was not isolated from any root samples. Unidentified species of Leptographium and Graphium Corda isolated from root samples were included in certain analyses.

The SPB plots sampled were either under current attack or were recently vacated (within 2 weeks of sample) as determined by presence of fresh pitch exudates or tubes, off-color foliage, and presence or absence of exit holes in the bark of attacked trees. Stand characteristics were similar between SPB-attacked and control plots (Table 1). Control and SPB plots within natural stands or plantations also had similar stand characteristics (Table 2). The proportion of blue-stain fungi isolated from plots in either plantations or natural stands was generally higher in the SPBinfested plots than in the control plots. However, only plots located in plantations had a significantly higher proportion of blue-stain fungi in SPB-attacked plots than in the control plots (Table 2). Control plots with blue-stain fungi, including those not identified to species, tended to have higher total basal area than did control plots from which no blue-stain fungi were isolated. SPB plots with blue-stain fungi had a higher 10-year growth increment than those SPB plots from which no blue-stain fungi were isolated (Table 3).

When all three identified blue-stain spe-

cies were pooled, a significantly higher frequency of occurrence of these fungi was present in the roots of SPB-infested plots (50\%) relative to the control plots $(25 \%)$ (Table 4). Overall, blue-stain fungal isolates, including the unidentified Leptographium and Graphium isolates, also had a higher frequency of occurrence in the SPB plots $(87.5 \%)$ as compared to control plots $(45 \%)$. Of the three identified bluestain species, only L. terebrantis was pres-

Table 1. Comparison of stand characteristics between control and southern pine beetle (SPB) paired plots

\begin{tabular}{lccc}
\hline & \multicolumn{2}{c}{ Mean } & \\
\cline { 2 - 3 } Stand characteristics & Control & SPB & P value \\
\hline Total basal area, $\mathrm{m}^{2} / \mathrm{ha}$ & 28.1 & 25.9 & 0.14 \\
Pine basal area, $\mathrm{m}^{2} / \mathrm{ha}$ & 25.4 & 23.7 & 0.26 \\
DBH, cm & 22.6 & 22.6 & 0.93 \\
Age, years & 25.5 & 25.3 & 0.84 \\
Height, m & 19.2 & 19.6 & 0.31 \\
5-year radial growth, cm & 3.9 & 3.8 & 0.82 \\
10-year radial growth, cm & $9.3^{\mathrm{b}}$ & $8.7^{\mathrm{b}}$ & $0.14^{\mathrm{b}}$ \\
Site index & , m & 28.2 & 0.11 \\
\hline
\end{tabular}

${ }^{a}$ Results of a paired $t$ test comparing differences between variables for 40 paired plots from the control and SPB infested stands.

${ }^{\mathrm{b}} N=37$ paired plots.

${ }^{c}$ Site index based on height of codominant trees at age 50 .

Table 2. Means of stand characteristics for control and southern pine beetle (SPB) infested paired plots in natural stands or plantations

\begin{tabular}{|c|c|c|c|c|c|c|}
\hline \multirow[b]{2}{*}{ Stand characteristics } & \multicolumn{3}{|c|}{ Natural stands ${ }^{\mathbf{a}}$} & \multicolumn{3}{|c|}{ Plantations $^{b}$} \\
\hline & Control & SPB & $P$ value ${ }^{c}$ & Control & SPB & $P$ value \\
\hline Total basal area $\left(\mathrm{m}^{2} / \mathrm{ha}\right)$ & 26.2 & 23.9 & 0.506 & 28.7 & 26.6 & 0.193 \\
\hline Pine basal area $\left(\mathrm{m}^{2} / \mathrm{ha}\right)$ & 19.8 & 21.6 & 0.491 & 27.3 & 24.5 & 0.112 \\
\hline $\mathrm{DBH}(\mathrm{cm})$ & 25.6 & 26.9 & 0.382 & 21.6 & 21.3 & 0.468 \\
\hline Age (years) & 35.8 & 38.6 & 0.348 & 22.1 & 20.9 & 0.097 \\
\hline Height $(\mathrm{m})$ & 21.3 & 23.2 & 0.105 & 18.5 & 18.4 & 0.904 \\
\hline 5 -year radial growth $(\mathrm{cm})$ & 2.8 & 2.9 & 0.782 & 4.2 & 4.1 & 0.731 \\
\hline 10 -year radial growth $(\mathrm{cm})$ & $6.7^{\mathrm{d}}$ & $6.5^{\mathrm{d}}$ & $0.677^{\mathrm{d}}$ & $10.1^{\mathrm{e}}$ & $9.4^{\mathrm{e}}$ & $0.160^{\mathrm{e}}$ \\
\hline Site index (m@ age 50) & 25.9 & 26.2 & 0.758 & 28.0 & 28.9 & 0.095 \\
\hline Proportion of blue-stain fungi & 0.30 & 0.50 & $0.625^{\mathrm{f}}$ & 0.37 & 0.80 & $0.002^{\mathrm{f}}$ \\
\hline
\end{tabular}

${ }^{\text {a }} N=10$ paired plots.

${ }^{\mathrm{b}} N=30$ paired plots.

${ }^{c} P$ values were obtained from a paired $t$ test based on the difference between control and SPB plots for the specified stand characteristics.

${ }^{\mathrm{d}} N=$ nine paired plots.

${ }^{\mathrm{e}} N=28$ paired plots.

${ }^{\mathrm{f}}$ McNemar test.

Table 3. Stand characteristics for plots without and with the presence of blue-stain fungi in the control and southern pine beetle (SPB) plots

\begin{tabular}{|c|c|c|c|c|c|c|}
\hline \multirow[b]{2}{*}{ Stand characteristic } & \multicolumn{3}{|c|}{ Control } & \multicolumn{3}{|c|}{ SPB } \\
\hline & $\begin{array}{c}\text { Without } \\
N=26\end{array}$ & $\begin{array}{c}\text { With } \\
N=14\end{array}$ & $P$ value ${ }^{a}$ & $\begin{array}{c}\text { Without } \\
N=11\end{array}$ & $\begin{array}{c}\text { With } \\
N=29\end{array}$ & $P$ value \\
\hline Total basal area, $\mathrm{m}^{2} / \mathrm{ha}$ & 26.3 & 31.5 & 0.045 & 24.5 & 26.4 & 0.392 \\
\hline Pine basal area, $\mathrm{m}^{2} / \mathrm{ha}$ & 23.9 & 28.21 & 0.146 & 23.0 & 24.0 & 0.670 \\
\hline $\mathrm{DBH}, \mathrm{cm}$ & 22.3 & 22.9 & 0.728 & 22.9 & 22.6 & 0.905 \\
\hline Age, years & 26.3 & 24.1 & 0.437 & 29.4 & 23.8 & 0.100 \\
\hline Height, $\mathrm{m}$ & 19.0 & 19.5 & 0.692 & 20.3 & 19.4 & 0.521 \\
\hline 5-year radial growth, $\mathrm{cm}$ & 3.9 & 3.8 & 0.873 & 3.1 & 4.1 & 0.076 \\
\hline 10 -year radial growth, $\mathrm{cm}$ & $9.2^{\mathrm{b}}$ & $9.5^{\mathrm{c}}$ & 0.751 & $6.4^{\mathrm{d}}$ & 9.3 & 0.034 \\
\hline Site index, $\mathrm{m} @$ age 50 & 27.0 & 28.3 & 0.265 & 27.2 & 28.6 & 0.280 \\
\hline
\end{tabular}

a $P$ value obtained from a two-sample $t$ test of the difference between plots without and with bluestain fungi for the specified stand characteristic.

${ }^{\mathrm{b}} N=24$ paired plots.

${ }^{\mathrm{c}} N=13$ paired plots.

${ }^{\mathrm{d}} N=$ eight paired plots. 
Table 4. Percentage of southern pine beetle (SPB) and control plots with each type of blue-stain fungus and tests for significance

\begin{tabular}{|c|c|c|c|}
\hline \multirow[b]{2}{*}{ Blue-stain fungus } & \multicolumn{2}{|c|}{ Percent blue-stain fungi isolated } & \multirow[b]{2}{*}{$P$ value } \\
\hline & SPB plots & Control plots & \\
\hline Ophiostoma ips & 30.0 & 17.5 & 0.27 \\
\hline Leptographium terebrantis & 27.5 & 2.5 & 0.001 \\
\hline Leptographium procerum & 22.5 & 15.0 & 0.51 \\
\hline All three species pooled & 50.0 & 25.0 & 0.03 \\
\hline All blue-stain genera ${ }^{b}$ & 87.5 & 45.0 & 0.001 \\
\hline
\end{tabular}

${ }^{a}$ Differences between SPB and control plots for percentages of blue-stain fungi were tested with the McNemar test.

${ }^{\mathrm{b}}$ Includes unidentified Leptographium and Graphium spp.

\section{SPB}

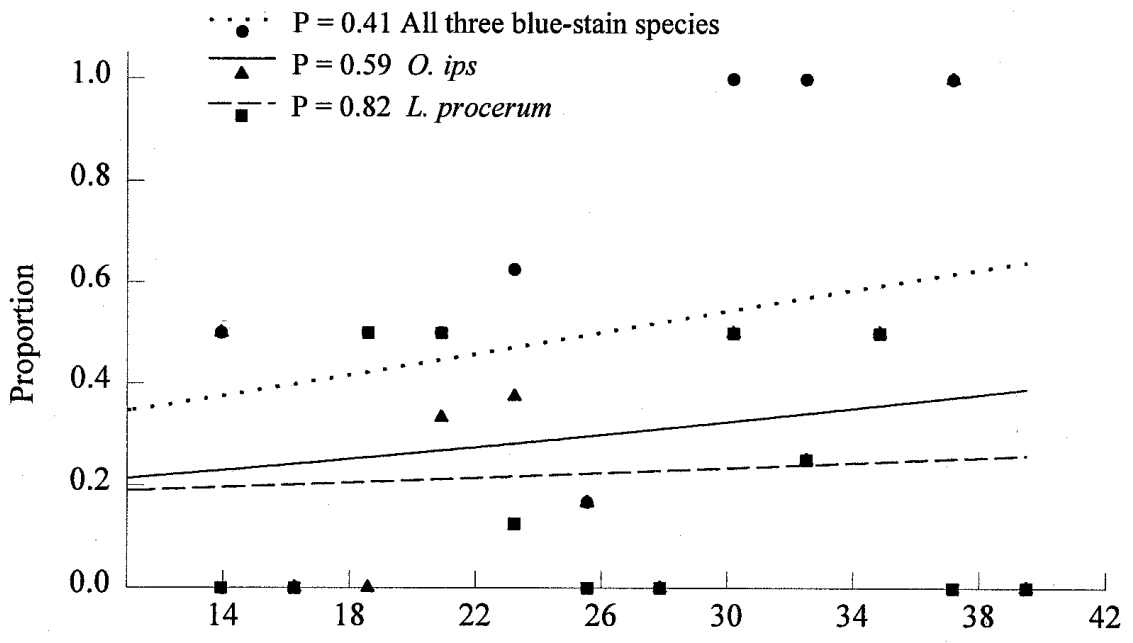

Total basal area $\left(\mathrm{m}^{2} / \mathrm{ha}\right)$

\section{CONTROL}

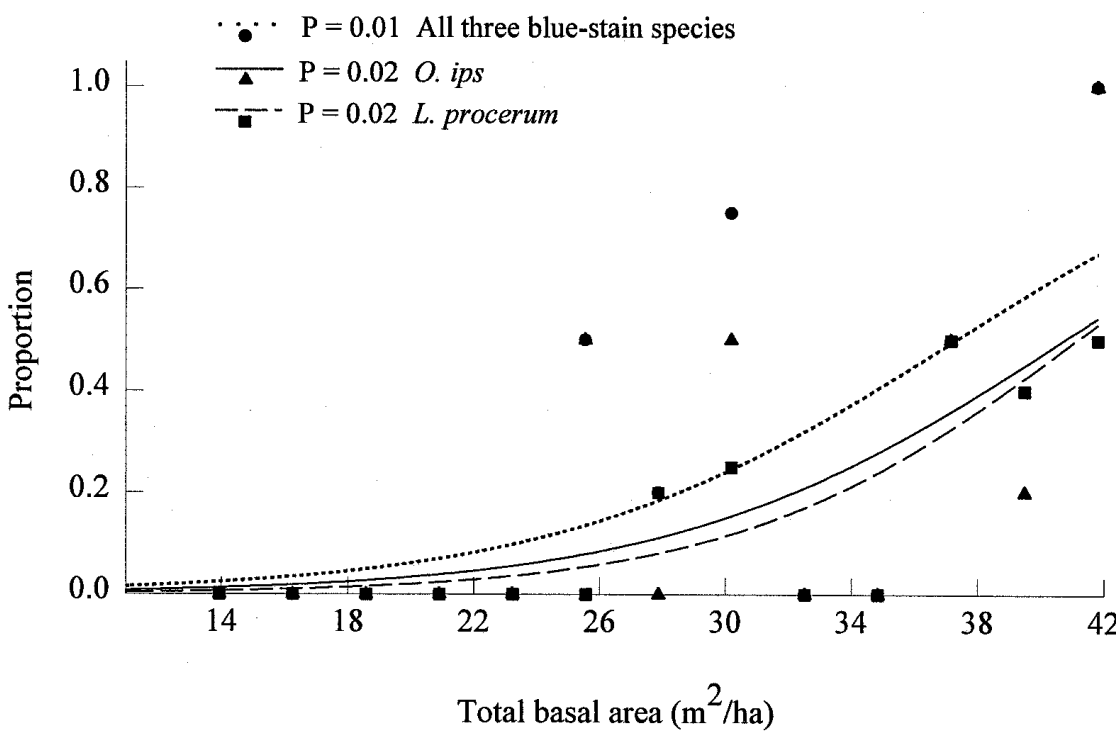

Fig. 1. Three logistic regression models for the proportion of plots having blue-stain fungi expressed as a function of total basal area $\left(\mathrm{m}^{2} / \mathrm{ha}\right)$ in southern pine beetle (SPB) and control plots. The curves, associated data points, and $P$ values for SPB and control plots represent pooled data for all three blue-stain species (Ophiostoma ips, Leptographium terebrantis, and L. procerum) and individual data for the blue-stain species $O$. ips and $L$. procerum. ent in significantly more plots infested by the SPB $(27.5 \%)$ than in control plots (2.5\%). O. ips and L. procerum also were numerically present more frequently in SPB than in control plots (Table 4).

Among the stand variables measured, only total basal area of the control plots was significant in the logistic regression model with respect to the occurrence of the identified species of blue-stain fungi (Fig. 1). The logistic model with all three bluestain fungal species pooled was significant at $P=0.01$ while the models for $O$. ips and $L$. procerum were each significant at $P=$ 0.02. The logistic model for L terebrantis could not be fit because of the low frequency of occurrence of this fungus in the control plots. The SPB plots were nonsignificant for any stand variables relative to the three blue-stain fungal species.

\section{DISCUSSION}

There is an association between SPB attacked trees and presence of blue-stain fungi in southern pine roots. Little is known about the role of these fungi in pine roots with respect to their effects on predisposition of trees to attack, although evidence associating these fungi with declines of various pine species is mounting $(11,17,22)$. Resinous lesions and staining in sampled roots associated with isolation of $L$. procerum, $O$. ips, and $L$. terebrantis were observed. In the control plots, no crown symptoms were observed in trees where we isolated these fungi from roots. Pathogenicity of these fungi to loblolly pine stem tissues has been demonstrated (21); however, the mechanisms involved in root infection remain unknown in this tree species. The black turpentine beetle, Dendroctonus terebrans Oliv., attacks the basal stem and large roots of various pine species. The three blue-stain fungal species identified in this study are also reported to be carried by $D$. terebrans (24) and $L$. terebrantis has been associated with mortality in various pine species $(16,23,24)$. Black turpentine beetle attacks were observed only in one sampled tree in three plots and was therefore not considered a factor influencing the occurrence of $L$. procerum, $O$. ips, and L. terebrantis. Rootfeeding bark beetles (Coleoptera:Scolytidae) have been implicated as vectors or wounding agents in conifer root diseases caused by various blue-stain fungi $(11,17,20)$. In this study, L. terebrantis was highly associated with SPB-attacked plots, and this fungus is reportedly one of the more pathogenic among blue-stain fungi attacking loblolly pine (21). The potential exists for pathogenicity of blue-stain fungi on certain conifer hosts in the absence of insect vectors $(10,14,19)$.

While both plantations and natural stands had higher proportions of blue-stain fungi in SPB plots than in control plots, only plantations had a significantly higher proportion of these fungi in the SPB plots. 
The smaller sample size of 10 natural stands versus 30 plantations may account for this. Stand characteristics between control and SPB plots were equivalent in both types of stands. While stand characteristics were not statistically analyzed between plantations and natural stands, plantations had about $25 \%$ greater basal area, tended to be younger, and had higher growth rates than natural stands. Further studies on the distribution of blue-stain fungi with respect to stand origin and relationships to SPB attack are needed.

It is axiomatic that maintenance of optimal basal area is a primary requisite for stand health and productivity in a variety of coniferous forest types $(6,8,13,15)$. The significant logistic relationship found between increasing stand basal area and frequency of occurrence of $O$. ips, L. procerum, and the combination of these fungi and L. terebrantis in the non-attacked control stands may be a consequence of high stand density resulting in an increased likelihood that stress factors such as drought might become important in predisposing stands to SPB attack (25). Thus, the presence of these fungi relative to stand density may serve as a risk indicator with respect to SPB attack. Whether these fungi and other blue-staining pathogenic fungi play roles as primary predisposing agents to bark beetle attack or whether they are secondary root colonizers of previously stressed trees must be determined by further research. On the other hand, we speculate that the production of resinous lesions in apparent response to infection by these fungi indicates the tree is expending a certain amount of energy capital for the production of defensive compounds. The energy expenditure elicited by these rootinfecting fungi, in turn, could result in diminished host defensive response to beetle attack. After successful attack initiation by the SPB as governed by tree physiological status, climatic conditions, beetle populations, and other factors, enhanced colonization of tree roots by bluestain fungi may take place as a consequence of attack. This may account for the even distribution of these fungi regardless of stand basal area in the SPB-attacked plots.
Further research needs to be conducted on the significance of these fungi in relation to SPB attack. This research should be directed toward the understanding of relationships between possible vectors, soil and site factors, root distribution, and the role of these fungal complexes in predisposition of stands to SPB attack.

\section{LITERATURE CITED}

1. Alexander, S. A., and Carlson, J. A. 1989. Visual damage survey project manual. Forest Response Program, USEPA National Council for Air and Stream Improvement. VPI and SU, Blacksburg, VA. 53 pp.

2. Alexander, S. A., Skelly, J. M., and Webb, R. S. 1981. Effects of Heterobasidion annosum on radial growth in southern pine beetleinfested loblolly pine. Phytopathology 71:479-481.

3. Barnard, E. L., Blakeslee, G. M., English, J. T., Oak, S. W., and Anderson, R. L. 1985. Pathogenic fungi associated with sand pine root disease in Florida. Plant Dis. 69:196-199.

4. Barnard, E. L., Gilley, S. P., and Dixon, W. N. 1991.Incidence of Heterobasidion annosum and other root-infecting fungi in residual stumps and roots of slash pine plantations in Florida. Plant Dis. 75:823-828.

5. Conover, W. J. 1980. Practical Nonparametric Statistics, 2nd ed. John Wiley \& Sons, New York.

6. Ferrell, G. T., Otrosina, W. J., and DeMars, C. J. 1994. Predicting susceptibility of white fir during an outbreak of the fir engraver beetle. Can. J. For. Res. 24:302-305.

7. Ferrell, G. T. and Parmeter, J. R., Jr. 1989. Interactions of root disease and bark beetles. In: Proceedings of the Symposium on Research and Management of Annosus Root Disease (Heterobasidion annosum) in Western North America. USDA Forest Service Gen. Tech. Rep., PSW-116, Berkeley, CA.

8. Ferrell, G. T., and Smith, R. S. 1976. Indicators of Fomes annosus root decay and bark beetle susceptibility in sapling white fir. Forest Sci. 22:365-369.

9. Harrington, T. C. 1988. Leptographium species, their distributions, hosts, and insect vectors. In: Leptographium Root Diseases on Conifers. T. C. Harrington and F. W. Cobb., Jr., eds. American Phytopathological Society Press, St. Paul, MN.

10. Harrington, T. C., and Cobb, F. W., Jr. 1983. Pathogenicity of Leptographium and Verticicladiella spp. isolated from roots of western North American conifers. Phytopathology 73:596-599.

11. Harrington, T. C., and Cobb, F. W., Jr. 1988. Leptographium Root Diseases on Conifers. American Phytopathological Society Press, St. Paul. MN.

12. Hertel, G. D., Branham, S. J., and Swain, K.
M. 1985. Technology transfer in integrated pest management in the South. USDA Forest Service, Gen. Tech. Rep., SE-34. Asheville, NC.

13. Hertert, H. D., Miller, D. L., and Partridge, A D. 1975. Interaction of bark beetles (Coleoptera:Scolytidae) and root-rot pathogens in grand fir in northern Idaho. Can. Ent. 107:899-904.

14. Hicks, B. R., Cobb, F. W., Jr., and Gersper, P. L. 1980. Isolation of Ceratocystis wagener from forest soil with a selective medium. Phytopathology 70:880-883.

15. Hicks, R. R., Jr. 1980. Climatic, site, and stand factors. In: The Southern Pine Beetle. R. C. Thatcher, J. L. Searcy, J. E. Coster, and G. D. Hertel, eds. USDA Forest Service, Science and Education Administration Tech. Bull. No. 1631.

16. Highley, L., and Tattar, T. A. 1985. Leptographium terebrantis and black turpentine beetles associated with blue stain and mortality of black and Scots pines on Cape Cod, Massachusetts. Plant Dis. 69:528-530.

17. Klepzig, K. D., Raffa, K. F., and Smalley, E. B. 1991. Association of an insect-fungal complex with red pine decline in Wisconsin. For. Sci. 37:1119-1139.

18. Livingston, W. H., Mangini, A. C., Kinzer, H G., and Mielke, M. E. 1983. Association of root diseases with bark beetles (Coleoptera:Scolytidae) in Pinus ponderosa in New Mexico. Plant Dis. 67:674-676.

19. Mathre, D. E. 1964. Pathogenicity of Ceratocystis ips and Ceratocystis minor to Pinus ponderosa. Contrib. Boyce Thompson Inst. 22:363-388.

20. Nevill, R. J., and Alexander, S. A. 1992. Pathogenicity of three fungal associates of Hylobius pales and Pissodes nemorensis (Coleoptera:Curculionidae) to eastern white pine. Can. J. For. Res. 22:1438-1440.

21. Nevill, R. J., Kelley, W. D., Hess, N. J., and Perry, T. J. 1995. Pathogenicity to loblolly pines of fungi recovered from trees attacked by southern pine beetles. South. J. Appl. For. 19:78-83.

22. Otrosina, W. J., Hess, N. L., Jones, J. P., Zarnoch, S. J., and Perry, T. J. 1995. Relationships between blue-stain fungi in roots of loblolly pine and southern pine beetle attack. (Abstr.) Phytopathology 85:1198.

23. Raffa, K. F., and Smalley, E. B. 1988. Host resistance to invasion by lower stem and root infesting insects of pine: Response to controlled inoculations with the fungal associate Leptographium terebrantis. Can. J. For. Res. 18:675-681.

24. Rane, K. K., and Tattar, T. A. 1987. Pathogenicity of blue-stain fungi associated with Dendroctonus terebrans. Plant Dis. 71:879883.

25. Showalter, T. D., and Turchin, P. 1993. Southern pine beetle infestation development: Interaction between pine and hardwood basal areas. For. Sci. 39:201-210. 